\title{
STOKVELS AS AN INSTRUMENT AND CHANNEL TO EXTEND CREDIT TO POOR HOUSEHOLDS IN SOUTH AFRICA
}

\author{
Polly Mashigo* \\ Tshwane University of Technology \\ mashigomp@tut.ac.za \\ Christie Schoeman\# \\ University of Johannesburg \\ christies@uj.ac.za
}

December 2011

\begin{abstract}
The aim of the article is to investigate the possible use of traditional stokvels as a channel or conduit to give poor households access to much-needed cash. Cash and access to cash or credit is central to economic life. The hypothesis of the article is that traditional stokvels in South Africa can be used in their existing form, when pooled, as a special purpose vehicle (SPV) to extend much-needed cash to poor households in order to smooth their consumption. In dealing with uncertainty, the traditional stokvels ensure reliable and predictable behaviour in a mechanism that makes it possible to supply credit at low cost and risk.
\end{abstract}

\section{Keywords}

Group lending mechanism, stokvel, social securitisation, special purpose vehicle, formal financial sector, irreducible uncertainty

\footnotetext{
*Dr Polly Mashigo is a senior lecturer in the Department of Economics at the Tswane University of Technology, Pretoria, South Africa.

\#Dr Christie Schoeman is a senior lecturer in the Department of Economics and Econometrics at the University of Johannesburg, South Africa.
} 


\section{INTRODUCTION}

A stokvel can, in general terms, be defined as an umbrella term used to describe informal savings organisations in the African community in South Africa. Stokvels operate mainly in black areas, and have social, economic and entertainment functions (Verhoef, 2002). The aim of the paper is to construct a conceptualised theoretical sound taxonomy of a social institution (a traditional stokvel) to substantiate the placement of stokvels in the existing financial economic reality. To rationalise the possible use of traditional stokvels as a channel or conduit to give poor households access to much-needed cash, be it in the form of credit or saved-up own funds which are bound under social contract. The hypothesis that is rationalised and founded by a taxonomy of a stokvel in this paper is that stokvels in South Africa can be used in their existing form, without adjustment and under limiting conditions as reflected by a system of principles (Mashigo \& Schoeman (2011), as a special purpose vehicle (SPV) and conduit to extend credit to the poor (see Smith, 2008, for a comprehensive but accessible exposition on securitisation).

Due to the nature of a traditional stokvel, an institution which is built in accordance with specific rules or social technology (Mashigo \& Schoeman, 2011), a traditional stokvel cannot be assumed to be a given economic reality or fact. The problem of wrong assumptions being made and spurious outcomes generated, as proposed in Mashigo and Schoeman (2011), is real. See for example Copeland (2000), Stiglitz (1981) and Summers (1986) on the conventional assumptions on market efficiency and, in a related argument, Davidson (1993) and Meehl (1997) for a clear and readable theoretical view. The conventional wisdom on or assumptions about traditional stokvels (stokvels in the rest of the paper) propose that stokvels are informal banks or savings institutions, in principle the same as a formal savings institution like Capitec, implying that stokvels have a profit-taking motive (an economic goal) rather than trust (a social goal) as rationale for their origin and existence. Is a stokvel at all this kind of economic institution? On what basis and empirics do they relate to banks or saving institutions? According to Mashigo and Schoeman (2011), the answer to this proposition is negative. If negative, then, how can this social technology still be used to relieve poor subjects from the economic realities that negatively affect their wealth? This is the research question and the argument for the study.

Cash and access to cash or credit is central to economic life. Because of its peculiar nature, cash is needed for day-to-day consumption and plays an indispensable precautionary role in the smoothing of consumption (Wilson, 1996; Wright, 2000). In the presence of the illiquid and irreversible nature of the assets of the poor, their vulnerability to random events or shocks and their uncertainty about future prospects, cash or access to credit is much needed to smooth consumption. According to Meagher and Wilkinson (2001), Whiteford and McGrath (2000), and Mashigo and Schoeman (2011), access to credit is instrumental for development through the social empowerment role it plays by motivating income-generating activity, responsible behaviour and economic independence, by taxing irresponsible behaviour and by economising on scarce resources to be allocated to the development of alternative institutions (training and education) to insure against real and unmanageable market-related hardship.

The formal financial sector, i.e. banks and other non-bank suppliers of credit, does not accommodate the need for credit by poor households because of the problem of imperfect information or informational uncertainty about them and the irreducible uncertainty of the economic environment of the poor (Bernanke, 1980). Quantification of risk under these circumstances is difficult. This means that poor households are denied access to cash and are without sufficient hedges against the severe impact of relatively minor adverse events like 
temporary illness. They cannot rely on financial intermediation and therefore remain deprived of need-based credit.

In these circumstances, the traditional informal financial sector exemplified by stokvels is very important in providing credit to poor households. Traditional institutions and instruments have a history of success and have for some time made access to credit possible for even the poorest of the poor. Savings and credit networks like stokvels have not received recognition or support commensurate with their current and potential contribution to improving the living standards of the economically marginalised majority (Baumann, 2001; Johnson \& Rogaly, 1997; Mjoli-Mncube, 2003; World Bank, 2002).

Close analysis in the paper reveals that stokvels originated and function rather like collective insurance mechanisms in many ways (see Mashigo \& Schoeman, 2011 for a substantiated motivation). It seems that stokvels are not traditional intermediation institutions taking deposits, supplying loans and profiting through interest spreads from transforming time and accepting risk, as is generally believed.

Stokvels can be used in their existing form, without adjustment, as a special purpose vehicle (SPV) and conduit to extend credit to the poor. This paper will formulate and argue for this hypothesis. Section 2 will highlight and review the theory and literature on the role played by cash in insuring risk and in smoothing income in general and specifically in the case of the poor. Section 2 will also review the theory and literature on the underlying components of social securitisation that insures liable behaviour in an irreducibly uncertain and hostile economic environment. The role played by non-economic factors in the latter will be analysed. In section 4 , the role that can be played by stokvels to insure and smooth consumption when formally institutionalised will be analysed. The paper concludes with a synthesis on the ability of a pool of stokvels to act as a possible instrument and conduit for credit to the poor.

\section{THEORY AND LITERATURE OVERVIEW}

\subsection{The importance of cash to smooth consumption}

Cash and credit play an indispensable role in smoothing consumption when assets are illiquid. The objective of this section is to analyse existing theoretical and empirical evidence on the role cash and credit play to reduce transaction costs and as an insurance mechanism under irreducible uncertainty and the high susceptibility of incomplete capital markets to all kind of shocks. Uncertainty in this paper refers to situations where the information available on future events is vague and cannot be summarised by a probability measure (Epstein, 1998). The future is irreducibly uncertain in the absence of any regularity (Davidson, 1991; Bernanke, 1980). In an irreducibly uncertain economic environment economic subjects rely on existing conventions, liquidity and animal spirits to bridge irreducible uncertainty (Keynes, 1936).

Shocks are as real for poor households as for the affluent, though much more devastating. Shocks destroy not only value for the poor but basic consumption as well. The extension of credit facilities to the poor can help to hedge against the individual or idiosyncratic risk that is especially problematic for the poor and in so doing smooth income to make the poor less dependent on and vulnerable to costly hand-outs and grants from the government. Idiosyncratic risk in this paper refers to a situation in which a portion of the population incurs income losses that do not affect the aggregate consumption of the population. Evidence indicates that 
government programmes like grants cannot help to solve the problem of idiosyncratic risk and are not efficient and effective in reducing the effects of adverse common or market shocks losses affecting aggregate consumption - due to operational inefficiencies and financial constraints.

The basic theoretical requirement for smoothing consumption and full insurance is to diversify fully idiosyncratic risk (Townsend, 1995; Treynor, 1962; Sharpe, 1964). This can only be done in the presence of free access to a multiple of fully reversible liquid assets, no transaction costs and an imperfect correlation between the different assets (Markowitz, 1952). Also assumed are the availability of a riskless asset (asset with riskless return), free access to loans at the riskfree rate (Tobin, 1958), and the ability to construct a portfolio which is constrained but identical to the market portfolio (Treynor, 1962; Sharpe, 1964). The requirements can be adhered to in theory by investing in market-related equity trusts, indices or mutual funds.

These opportunities do not exist for the cash- and asset-constrained poor, who struggle merely to survive. The limited, irreversible and covariant nature of their assets limits diversification opportunities, and this makes even self-insurance ineffective and costly. The illiquidity is due to high switching, transferring and storing costs, uncertainty about value and the inability of these assets to act as collateral. This leaves the poor vulnerable and exposed to adverse market (because of the low quality of government support) and idiosyncratic shocks (Yaron, Benjamin \& Charitonenko, 1998). The alternative is in many instances only dysfunctional and constrained government support. The limited diversification opportunities to smooth consumption force them under these circumstances either to self-insure at high cost, as already indicated, or to resort to degenerating opportunistic behaviour (e.g. criminal activity) to recover from shocks. This behaviour results in many instances in increasing inefficiency in the allocation of scarce resources at high on-going cost, which drains the community as well as government financially and socially.

Credit hedges the cost associated with the irreversible, illiquid, real capital assets of the poor in the presence of shocks. Credit ensures relatively smooth consumption in the presence of irreversible illiquid assets and shocks at no cost if related to the implied effects of a shock. The positive role of cash or credit originates from the dependence of the poor on assets, and the high transaction or reversing cost of these assets in times of shocks (Faig, 2000; Perold, 2004).

Credit therefore plays an indispensable role among the affluent and even more so in poor communities in an irreducibly uncertain environment (Gertler, Levine \& Moretti, 2003; Faig, 2000). In a situation of privately owned capital and the resultant shock-susceptible environment as in the capitalist system, there is even more reason for access to credit to insure risk (Faig, 2000).

Empirical evidence also demonstrates the economic importance of cash and access to credit for poor households to insure against idiosyncratic risk and to smooth consumption (Murdoch, 1999; Gertler \& Gruber, 2001; Gertler et al., 2003). Contrary evidence in this regard (Coleman, 1999) can be attributed rather to non-liable opportunistic behaviour, due to adverse selection and moral hazard (e.g. racketeering) and misuse due to shortcomings in the microfinance/lending mechanisms and institutions.

Cash and credit not only have a theoretical role to play in the welfare of the poor: evidence also points to the practical role of credit. Conventional government programmes to curb adverse shocks through subsidies, mandates, or direct government provision of health insurance and disability insurance can therefore be supported by micro-finance programmes to insure 
idiosyncratic risk at a fraction of the cost of conventional mechanisms (Gertler et al., 2003; yaron et al., 1998).

\subsection{Irreducible ignorance, uncertainty and social securitisation}

Formal credit is not available to poor households due to irreducible ignorance or uncertainty rooted in high sunk or irreversible costs associated with, inter alia, small short-term loans, monitoring of loans, default, the absence of collateral and the establishment and maintenance of financial facilities in poor rural areas. Credit is also not available to poor households for pure risk-return reasons. Due to the economies of scale in the financial sector and risk-return considerations, a small number of large long-term loans are much more profitable and less risky for banks than a multiple of small loans. The negative effects of these economic considerations are multiplied by the endemic nature of irreducible uncertainty in poverty-constrained situations. The objective of this section is to illustrate by theoretical evidence and example that irreducible uncertainty can be bridged in the same manner as securitisation or the managed pooling of financial assets smoothes financial return. Social securitisation by pooling social capital assets is indirectly able to smooth income and consumption. This is the actual rationale for the existence of stokvels (the statement will be substantiated later in the paper).

It is assumed in mainstream economic theory that uncertainty is identical to risk - that is, a single probability measure on a state of the world is available to guide choices or evaluate the expected value of pay-offs to different actions (Miao, 2003; Cagliarini \& Heath, 2000; Davidson, 1991). The fundamental premise is that either individual agents and/or the market can, at some cost, obtain reliable information about the future by analysing past and present market data (in the form of price signals). Knight (1921), Keynes (1936) and others argue, though, that irreducible uncertainty is more common in decision-making. If the environment is uncertain, and decision-makers are uncertain in their information-handling capacities, then it is unlikely that agents will have, or be able to possess, all the information they require to make an optimal decision.

People are therefore unable to form values about the future. Critical for success in this regard is to determine the economic-related social and psychological variables that influence and are responsible for decisions on utility that indicate or reflect probable future behavioural patterns and that, when considered, can assure or guarantee liable and predictable behaviour needed to bridge irreducible economic uncertainty. Many non-economic considerations are taken into account when decisions are made to bridge irreducible uncertainty. These non-economic considerations are very dynamic and pliable and can be adapted to ensure desired outcomes. People in an irreducibly uncertain economic environment obtain direct knowledge to bridge the irreducible uncertainty through direct acquaintance and through socialising and participation that directs decisions on the future (herd behaviour, for instance). These aspects frame and act as benchmarks for their decisions about the future under unreduced and by implication irreducible uncertainty (Kahneman \& Tversky, 1979).

Social practices and conventions in a group homogenise and create certainty about future prospects: the behaviour of the individuals contracted to the group's practices and conventions and prospects are insured by liability and loyalty to the group. Due to their role as a social ordering mechanism, groups can create an environment in which the individual can avert risk and irreducible uncertainty by pooling liability and possible loss in a collective way. The price paid for this, the monetary payment and the loss of independence are compensated for by more certain future prospects of a smoothed income. Social and psychological variables like 
collective good, loss and custom as non-economic variables have an important role to play in the determining of preferences and the weighing of a utility function in unreduced and by implication irreducible uncertainty (Barberis \& Thaler, 2002; Kahneman \& Tversky, 1979; Mashigo, 2007). The variables that influence motives are under these circumstances not all bounded by economic nature, are manageable and can be used to create certainty about prospects of a smoothed income and to insure liable behaviour (Rabin, 2001). Rather than take ignorance as irreducible and given, it is possible to find mechanisms that insure preferred outcomes and predictable behaviour by bridging the irreducibly uncertain environment. Ignorance can be bridged at low cost and future prospects of a smoothed income are securitised in the group context.

\section{GROUP LENDING MECHANISMS FOR INSURING OPERATIONAL AND FINANCIAL SUSTAINABLE INFORMAL CREDIT IN SOUTH AFRICA}

\subsection{The stokvel and the insuring of cash}

Porteous (2003; Newmarch, 2006) points out that micro-lending is heavily regulated in South Africa at high cost for those involved, and the legislation allows lenders to charge high interest rates. Lenders therefore do not need to explore alternatives, and the legislation has thus resulted in poor households not having access to credit. Micro-lending institutions therefore do not serve the credit needs of the poor. The objective of this section is to explore the possibility that stokvels can be used, with little adjustment, as a special purpose vehicle (SPV) and conduit to extend credit to poor households in South Africa.

Different types of stokvels exist:

- these take the form of savings,

- credit, and capital-generating clubs

- and funeral associations (Verhoef, 2002; Wixley, 2006).

Stokvels have a range of informal financial services accessible to poor households that contribute to their survival and the smoothing of income. These services are accessed through various types of stokvels, which provide finance (both savings and credit) for food, for unpredictable and expensive events such as illness and funerals, as well as for predictable ones like marriages and education that will affect consumption (Buijis, 2002; Mashigo, 2007; Newmarch, 2006; Verhoef, 2002; Wixley, 2006).

In the traditional informal financial sector, households save small amounts of cash (Karlan, 2007; Murdoch, 1999), inter alia, in stokvels and this cash is also lent or paid back directly to the households. Thus, stokvels play an important role as economic and social instruments in smoothing consumption and in improving the living standards and increasing the utility of poor households. The main sources of credit - traditionally and historically - have always been in the form of informal arrangements like stokvels, established by the households in various communities to suit their financial needs or to cushion themselves against shocks (Mashigo, 2007; Verhoef, 2002). For this reason the sector is regarded by poor households as an important and primary source of credit provision. The ability of stokvels to mobilise savings and to channel small loans to small borrowers in an efficient and equitable way reduces transaction costs and effectively deals with the problem of uncertainty by insuring certain prospects. 
A stokvel is in its nature and character a homogeneous, decentralised utility that caters for (insures) the specific motives and needs of its members by insuring specific prospects that would otherwise directly affect their consumption (Johnson and Rogaly, 1997). The members formulate their own informal rules or constitutions through their stokvels, which are flexible and simple and which improve access to both savings and credit to satisfy the goal function. These stokvels operate according to such rules or constitutions and effectively reduce uncertainty in this manner by changing uncertainty into risk, by summarising the future into a probability measure (Murdoch, 1999; Mashigo, 2007). All stokvel members are involved in formulating their own constitution and deciding how their stokvels operate. This implies member control and mutual monitoring of the activities of the stokvels. Some stokvels have written constitutions, but most of those in rural poor areas do not: their members know the rules by heart (Mashigo, 2007). Given the low levels of formal education in poor communities, and because many of the people are functionally illiterate, the terms and conditions of the constitution are written in the vernacular, and the choice of a written language depends on the location of the stokvel. Because of members' low level of education, the constitutions or rules are deliberately kept simple.

The constitutions are different and depend on the type and purpose or goal function of the stokvel. Each member has to contribute a fixed amount in cash each month and in most cases no penalty is imposed on late payments (Murdoch, 1999; Karlan, 2007, Verhoef, 2002). It is a norm in poor communities that stokvel members hold regular meetings, on a weekly, fortnightly, or monthly basis according to their constitutions. Those who arrive late are subjected to a fine to stress the role played by collective rules and liable behaviour. According to Mashigo (2007), the constitution encourages members not to skip any payment, as this will result in, for example, non-payment in the case of death in the family. In cases where a member needs money urgently, there is an opportunity to borrow conditionally from the stokvel under strict rules.

Membership of stokvels is voluntary. However, in some stokvels, the constitution stipulates that before a new member can be accepted into the stokvel, his or her reliability, trust and loyalty must be established: for example, if a person is known to have a drinking problem or a bad paying record, he or she will not be accepted, as there would be a distinct danger that he or she would not be able to keep up with contributions and abide by the constitution (Mashigo, 2007). There is normally no written contract for members when joining or leaving the stokvel as long as the member is up to date with his or her contribution before leaving the stokvel. Mashigo (2007) found that members are able to leave a stokvel with little difficulty, although at some cost in terms of the abdication and loss of all implied privileges. Because of the loss in terms of personal relationships, trust, loyalty and reputation among members, violation of the rules does not normally happen.

Of central importance in the sector are features such as reputation, trust, norms and interpersonal networks that can improve the efficiency of society by facilitating coordinated actions. Groups are formed and held together by social aspects or the knowledge they possess about one another (Ghatak \& Guinnane, 1999; Karlan, 2007). The common bond between members directs the operation of the stokvel. In addition to the functions performed by stokvels, the households like and prefer them because stokvels are also a way of deepening friendships, and the benefits of contributing money together give households a head start in their financial affairs. The actions of a member have a bearing on others and influence the viability of the informal financial operations. Reputation is acquired on the basis of individual behaviour that is observed by others. The degree of information that members have about one another, peer pressure and monitoring are found to be effective ways of reducing information 
and monitoring costs, thereby reducing the problem of moral hazard and adverse selection (Murdoch, 1999). All the knowledge - personal, social, economic, past and present - available and stored by different informal mechanisms in the stokvel completes information on the individual member and creates preference and motive for a specific outcome that makes individual decisions and outcomes unambiguous and predictable.

Stokvels therefore do not rely on collateral to guarantee loans, because social pressure and monitoring are substitutes for collateral (Jones et al., 2000). The members know that they depend entirely on the stokvels in cases of financial distress and therefore adhere to the set rules or constitutions. Failure to pay the subscription for a period may result in the expulsion of a member from the stokvel. The expelled member may be re-admitted on condition that he/she pays the arrears owed to the stokvel in instalments and at the duly constituted meetings. This is peer pressure exerted on each member and a strategy to maintain financial discipline, responsibility and commitment among the members, so as to maintain an individual's reputation and to spare him/her embarrassment upon a death in his/her family, for instance.

Close analysis therefore shows that a stokvel, in its aims, tradition and functioning, acts more like an insurance instrument than a savings or primitive financial intermediation institution. It seems that stokvels are not traditional intermediation institutions taking deposits, supplying loans and profiting through interest spreads from transforming time and accepting risk. They instead aim to insure certain or ensured outcomes or prospects for the collective, and the monetary result is rather an unclaimed monetary balance to the buyer of a policy in order to gain, in a primitive way, a fair premium to insure against specific contingencies (Murdoch, 1999). The direct and opportunity costs of stokvel membership do not compensate for the consumption sacrificed for greater consumption in future -- the argument for the motivation to save. Instead, current consumption is forgone to smooth consumption in future (Mashigo and Schoeman, 2011; Jones et al., 2000; Ghatak and Guinnane, 1999). The payment acts as a premium paid to insure certain future outcomes or prospects. The periodic payments of members and the once-off right on the sum of payments are, when analysed and in an abstract sense, a cheap way to insure against future adverse contingencies. In the absence of these contingencies the member receives back all premiums and sacrifices a relatively small amount or opportunity cost (loss of interest) compensated by the right on immediate liquidity to smooth consumption. This act has no effect on consumption. The premium paid is compensated for by reduced risk and smoothed consumption, an ideal hedge. The periodic contribution is a fair insurance premium veiled by a discounted yearly lump sum, the actual difference between what is received in insurance benefit and what was contributed. To contribute to and become involved in a stokvel only makes economic sense (monetary utility received) when viewed in the context of desired or positive prospects that will flow from a seemingly "expensive" relationship. With the payment obligation or regular premium the buyer gets the conditional right to or claim on future cash to smooth consumption (Kahneman and Tversky, 1979). The organic nature of a stokvel, through its constitution or contract, insures, by different mechanisms (reputation, trust, norms and interpersonal networks), liable behaviour that to a large extent eliminates the probability of social default - or insures against social default. The view advanced here is that the mechanism of the stokvel is therefore intended to hedge against or bridge specific adverse but irreducibly uncertain prospects to smooth consumption for the members in exchange for an insurance premium or payment, rather than to fulfil a generic intermediation function (Murdoch, 1999; Karlan, 2007). 


\subsection{Stokvels and credit extension to the poor}

The deficiencies of formal individual lending practice under uncertainty can be overcome by institutions building on "social assets" to resolve the constraints of low physical collateral in poor communities (Murdoch, 1999; Ghatak and Guinnane, 1999). Social collateral and insurance mechanisms to address irreducible uncertainty, such as the efficient tying-in of borrowers, differentiating between risky and safe members, attracting risky and safe members without discriminating on the basis of rates or premiums, but via joint responsibility, making use of the ability to enforce and monitor contracts and regular repayments, collateral substitutes and a consequent increase in return on financial and social equity, naturally exist in group dynamics and give insurance against default at relatively low cost. The objective of this section is to argue for the realignment of stokvels so that they can act as a conduit of much-needed cash to the poor while still performing their original traditional role.

The peer selection and lending activity in a stokvel are continuously affected by a lack of economic considerations and randomness in lending due to custom, and the social, personal and the specific decentralised nature and origin of these institutions. There are social constraints on calculable efficiency, which include selection biases based on gender, tribe and custom when deciding on members. Due to the vulnerability to idiosyncratic shocks and collective dependence, decisions are motivated and assessed by loss-avoiding social rationales like custom-determined thresholds and positions, rather than conventional rational axioms when optimising utility. This, however, gives protection against cheating and racketeering and buys certainty and sustainability in the collective at a cost much lower than the formal screening and monitoring that occurs in the formal sector.

While social selection aspects will homogenise the group and ensure loyalty (certainty), pure micro-financial economic considerations make it possible to discriminate without using discriminatory rates (premiums) in group lending against risky members and inducing safe members at the same time by charging a joint liability charge, thereby making the pooling of risk more efficient. Having a joint liability charge makes it possible to charge one flat interest rate or premium and by doing so risk-takers or risky members are not frightened away; and at the same time safe members or risk-averse members are attracted to the group. Because the probable default of risky members is higher for the group as a whole, they will pay a higher fraction of the joint liability charge or cost (Ghatak and Guinnane, 1999; Karlan, 2007). Riskaverse and risk-taking types can therefore be induced to join the group by low interest or premiums partly consisting of a high joint liability payment or a joint fixed cost. The group dynamics are also changed in favour of less risky or risk-averse behaviour by the loss, socially and financially, when members are expelled and lose all privileges and contributions. This joint liability charge or fixed premium means that risk-taking is more costly, and risk-averse behaviour is rewarded (Stiglitz, 1990).

By its nature, a stokvel therefore lends itself to be used as an instrument to extend credit as insurance to the poor in cases of idiosyncratic shock. Many economic decisions are characterised by monetary payment in exchange for a desirable future or prospect (Kahneman and Tversky, 1979). This is especially true when one tries to reduce loss in a very uncertain environment. The "certainty" about loss is very real for the poor and therefore motivates risky behaviour to avoid the negative certainty for a less probable outcome with higher loss that increases exposure (Kahneman and Tversky, 1979). By intervention, the risky behaviour can be changed. Individuals do not see insurance as a fair loser game. They see an insurance premium as fair if the net probable gain is greater than the current status quo, which is very daunting for 
the poor. Through contributing and paying a fair price for a positive prospect, liable behaviour is motivated: "people are expected to exhibit more risk seeking in deciding whether to accept a fair gamble than in deciding whether to purchase a gamble for a fair price" (Kahneman and Tversky, 1979). Certainty about gains increases aversion to losses and the desirability of gains. People, to a lesser extent, accept all randomness as fate - the reigning force of their future prospects - and actively manage their future. Stokvels are therefore, due to their characteristics of social coherence, collective liability, motives, preferences, utility considerations (social securitised nature), microstructure considerations and the law of large numbers (pool of pools), ideal instruments to be pooled into a vehicle to act as a conduit for extending credit to the poor.

Pooled stokvels can under these circumstances be used as a special purpose vehicle (SPV) to insure cash payments to the poor at relatively low cost. Banks may, for instance, sell a government cash insurance contract (conditioned government guarantee) to a structured pool of stokvels (SPV) as legal entity at an actuarial calculated value based on the existing history of their saving with a bank and reserves needed to guarantee specific risk. Following normal practice, stokvels in effect then sell cash securities or credit instrument to members, who pay a flat rate premium on a guaranteed block of cash. The premiums are paid to banks to uphold a minimum reserve at the bank, while the surplus is divided among non-claiming members first to ascertain a fair premium to guarantee full insurance, and the rest in ways to motivate the success and continuation of the stokvel. The bank therefore acts as the originator of government debt or guarantees and undertakes to service the pool of stokvels.

Through this system or SPV, banks have no increased risk, nor do they have larger capital requirements, extra administrative cost or costs of introducing new systems. Government does not actively have to budget and fund the extension of credit, and would only have a role in honouring guarantees in the event of default. The probability of default of the SPV (stokvels as a SPV), though, seems to be marginal due to the law of large numbers and the social and economic cost for individuals in the group who default (cheat).

\section{SYNTHESIS}

Stokvels' current place in the economy and the ability to meet the financial needs of poor households can be considered an opportunity to help to bridge the irreducibly uncertain economic environment which limits access to credit by the poor. Stokvels provide the opportunity for government and banks to develop mutually beneficial relationships or linkages with such informal associations to make them more effective and efficient in mobilising premiums (savings) and advancing credit in poor communities. In dealing with an irreducibly uncertain economic environment, stokvels have assured the liable and predictable behaviour needed to supply credit.

Forming groups (as in stokvels) is a means not only of delivering savings and credit services, but of building group skills as part of a wider strategy of financial empowerment. Group members in this case learn to manage finance (savings and credit), and are encouraged to formulate their own rules about the operation of their stokvels and impose their own discipline in relation to this finance. The long-term relationships between members in the community - their social interaction, trust, loyalty and reputation - play an important role, as they bind the members together and teach them to manage funds and especially to pay premiums on a regular basis. Individual liable behaviour is motivated by certain future outcomes or prospects. The 
effectiveness of stokvels lies in the fact that individuals are able to select creditworthy peers, monitor the use of loans (claims) and enforce repayment better than the formal financial institutions.

Compared to formal financial services, informal financial services or social connections embedded in stokvels generally make it possible to incur very low transaction costs, require less documentation for approving claims, no proof of employment, and no traditional collateral to secure loans. Of importance is that stokvels also possess a high degree of information about the behaviour and character of borrowers, and this enables stokvels to be used as a conduit to supply credit when the consequence of a shock needs to be overcome, in exchange for payment of a regular fair premium. Guarantees by government will not only give relief to the poor and encourage them to self-insure at low or no cost, but will at the same time motivate more liable behaviour.

Access to cash in this way is also instrumental to development through the social empowerment role it plays by motivating income-generating activity, responsible behaviour and economic independence, by taxing irresponsible behaviour and by contributing to economising on scarce resources that may alternatively be allocated to the development of institutions (training and education) to insure against real and unmanageable market-related hardship.

The synthesis that is the proposition developed in line with the hypothesis of this paper has to be tested. The technical and actuarial aspects and detail and a feasibility study of the proposition have to be researched. Formalised stokvel services like First National Bank's InContact Pro can be used as a platform to extend this service to insure cash for poor households. Perhaps the greatest challenge, however, is to avoid changing the original characteristics and fine social balance of the stokvel, as has so many times been attempted nationally and internationally, for profit instead of the supporting of trust or for one-sided financial gain. This is a unique social technology and asset that, when pooled, can become a vehicle for smoothing consumption and supporting financial and social upliftment in South Africa at relatively low cost.

\section{LIST OF REFERENCES}

Barberis, N. \& Thaler, R.A. (2002). Survey of Behavioural Finance. (NBER Working Paper 9222).

Baumann, T. (2001). Micro Finance and Poverty Alleviation in South Africa. Cape Town: Bay Research and Consultancy Services.

Bernanke, B.S. (1980). Irreversibility, Uncertainty and Cyclical investment. (NBER Working Paper, 502).

Buijis, G. (2002). Rotating Credit Associations: Their Formation and use by Poverty-stricken African Women in Rhini Grahamstown, Eastern Cape. University of Zululand.

Cagliarini, A. \& Heath, A. (2000). Monetary Policy in the Presence of Knightian Uncertainty. The College of Information Sciences and Technology, Australia: The Pennsylvania State University.

Coleman, B.E. (1999). The Impact of Group Lending in Northeast Thailand. Journal of Development Economics, 60, pp. 105-141.

Copeland, L.S. (2000). Exchange Rates and International Finance, $3^{\text {td }}$ edition. London: Pearson Education Limited. 
Davidson, P. (1991). Uncertainty in Economics: Keynes, Knowledge and Uncertainty. Journal of Economic Perspectives, 5(1), pp. 107-116.

Davidson, P. (1993). The Elephant and the Butterfly. Journal of Post Keynesians, 15(3), pp. 309-322. Epstein, L.G. (1998). A Definition of Uncertainty Aversion. Review of Economic Studies, 66, pp. 579608.

Faig, M. (2000). Money with Idiosyncratic Uninsurable Returns to Capital., Journal of Economic Theory, 94(2), pp. 218-240.

Gertler, P. \& Gruber, J. (2001). Insuring Consumption against Illness. American Economic Review, 92(1), pp. 51-70.

Gertler, P., Levine, D.I. \& Moretti, દ. (2003). Does Microfinance Help Families Insure Consumption against I/Iness? Institute of Business and Economic Research, University of California, C03(129).

Ghatak, M. \& Guinnane, T. (1999). The Economics of Lending with Joint Liability: Theory and Practice. Journal of Development Economics, 60, pp. 195-228.

Johnson, S. \& Rogaly, B. (1997). Microfinance and Poverty Reduction. London: Oxfam and Action Aid. Jones, H., Sakyi-Dawson, 0., Harford, N. \& Sey, A. (2000). Linking formal and informal financial intermediaries in Ghana: conditions for success and implications for the RNR development. Ghana: Oversees Development Institute (ODI).

Kahneman, D. \& Tversky, A. (1979). Prospect Theory: An Analysis of Decision under Uncertainty, Econometrica, 47(2), pp. 263-291.

Karlan, D.S. (2007). Social connections and group banking, The Economic Journal, 117, pp. F52-F82.

Keynes, J.M. (1936). The General Theory of Employment Interest and Money. London: MacMillan Company of Canada Limited.

Knight, F.H. (1921). Risk, Uncertainty and Profit. New York: Houghton Miffin.

Markowitz, H. (1952). Portfolio Selection. Journal of Finance, 7, pp. 77-91.

Mashigo, M.P. (2007). Extending Credit to the Low-income and Poor Households in South Africa: A System of Principles. . Doctoral thesis. Johannesburg: University of Johannesburg.

Mashigo, M.P. \& Schoeman, C. (2011). Microcredit and the transforming of uncertainty since 1976: International lessons for South Africa. New Contree Journal, 62, pp. 149-176.

Meagher, P. \& Wilkinson, B. (2001). Filling the gap in South Africa's small and micro credit market: An analysis of major policy, legal, and regulatory issues. Revised Final Report submitted to the Micro Finance Regulatory Council of South Africa, Maryland: IRIS Center, University of Maryland.

Meehl, P.E. (1997). The problem is epistemology, not statistics: Replace significant tests by confidence intervals and quantify accuracy of risky numerical predictions. In L.L. Harlow, S.A. Mulaik \& J.H. Stieger (eds.) What if there were no significance tests? Mahwah, NJ: Eribaum.

Miao, J (2003). Consumption and Saving under Knightian Uncertainty. Boston: Institute for Economic Development, Boston University.

Mjoli-Mncube, N. (2003, January 19). Banking on the People to Prosper. City Press, p. 4.

Murdoch, J. (1999). The Microfinance Promise. Journal of Economic Literature, 37(4), pp. 1569-1614. 
Newmarch, J. (2006). Financial Fitness: Saving with your Friends. [0n-line] Available: http://econrsa.org/home/index.php?option=com_docman\&task=doc. (Accessed 22 February 2010)

Perold, A. F. (2004). The Capital Asset Pricing Model. The Journal of Economic Perspectives, 18(3), pp. 3-24.

Porteous, D. (2003). The Past, Present and Future of Microfinance in S.A. Johannesburg: FinMark Trust. Rabin, M. (2001). A Perspective on Psychology and Economic. European Economic Review, 36(1), pp. $11-46$.

Sharpe, W.F. (1964). Capital Asset Prices: A Theory of Market Equilibrium under Conditions of Risk, Journal of Finance, 19(3), pp.425-442.

Smith, W.P.C. (2008). The Implication of Basel I/ on Securitisation Transactions of Banks. Unpublished Master's Dissertation. Johannesburg: University of Johannesburg.

Stiglitz, J.E. (1981). The allocation role of the stock market: Pareto optimality and competition. The Journal of Finance, 36(2), pp. 233-251.

Stiglitz, J.E. (1990). Peer Monitoring and Credit Markets, World Bank Economic Review, 4(3), pp. 351366.

Summers, L.H. (1986). Does the stock market rationality reflect fundamental values?. The Journal of Finance, 41(3), pp. 591-601.

Tobin, J. (1958). Liquidity Preference as Behaviour Towards Risk. Review of Economic Studies, 25, pp. 68-85.

Townsend, R.M. (1995). Consumption Insurance: An Evaluation of Risk-Bearing Systems in LowIncome Economies. Journal of Economic Perspectives, 9(3), pp. 83-102.

Treynor, J.L. (1962). Toward a Theory of Market Value of Risky Asset. Unpublished manuscript.

Verhoef, G. (2002). Money, Credit and Trust: Voluntary Savings Organisations in South Africa in Historical Perspective. Paper presented to the International Economic History Association Congress: Buenos Aires, Argentina, 22-26 July.

Wilson, G. (2001). Bank Management. Washington: McKinsey and Co.

Wixley, S. (2006). The Poor Philanthropist: How and Why the Poor Help Each Other. London:

Philanthropy.

Whiteford, A \& McGrath, M. (2000). Distribution of Income in South Africa. Pretoria: Human Science Research Council.

World Bank, The. (2002). Voices of the Poor from Many Land. USA: The World Bank Group.

Wright, G.A.N. \& Mutesasira, L. (2001). The relative risks to the savings of poor people. Kenya:

MicroSave Africa

Yaron, J., Benjamin, M. \& Charitonenko, S. (1998). Promoting Efficient Rural Financial Intermediation. World Bank Research Observer, 13(2), pp. 147-170. 